\title{
Logistics Implications of Urban Road Pricing
}

\author{
Matthias Klumpp and Torsten Marner \\ Institute for Logistics and Service Management, FOM University of Applied Sciences Essen, Essen D-45141, Germany
}

\begin{abstract}
Urban road pricing schemes are becoming increasingly popular among researchers and politicians as they promise a handle on increasing inner city traffic and economy as well as sustainable improvements for cities facing huge congestion and pollution problems. As in the cases of London and Stockholm, many European cities are going to implement such toll systems, especially as also the European Commission is voting for such pricing schemes in the recent white book on transportation and traffic. This research therefore provides a description of different urban road pricing schemes, their cost implications for city (last mile) transport as well as the decision and management options derived from these schemes for logistics companies. These options are furthermore checked regarding their advantages and disadvantages under the described toll schemes.
\end{abstract}

Key words: Urban road pricing, efficient city toll, last-mile logistics, global navigation satellite system, logistics impact.

\section{Introduction}

Congestion is one of the central problems of urban traffic. It results in time losses, emissions and accidents with negative welfare impacts. An efficient instrument to avoid this is road pricing that leads to a lower demand. With road pricing, individuals and companies have to decide whether to travel to the inner city and pay for it or not to drive and not to pay. Hence, unnecessary trips tend to be avoided and congestion can be mitigated [1-3]. This line of thought is presented in many concept papers and also the current European Commission White Paper [4] on transport regarding urban traffic concepts. It is also connected to many other developments in logistics, i.e., sustainability requirements, demographic change, expected transport volume increases and electric mobility concepts for cities $[5,6]$. A prominent example for a road pricing scheme is the London Congestion Charge that led to a significant decline of traffic volume. However, the greatest portion of the decline occurs in off-peak times. This is due to technological limitations of the system. Because of this, charges in London do not vary by time-of-day. Hence, the pricing scheme is not

Corresponding author: Matthias Klumpp, Dr., professor, research fields: logistics, supply chain management and qualification. E-mail: matthias.klumpp@fom-ild.de. load-dependent and with its flat rate character, it gives no incentives for an efficient use of scarce road space [7].

A pricing system based on GNSS (global navigation satellite systems, e.g., GPS (global positioning system), Galileo) ensures a usage-based approach as these systems are able to locate the vehicles within a certain area $[8,9]$. By this, load-dependent charging is feasible where charges are determined by the distance driven, the time of the trip and the position of each vehicle such as the implemented German toll collect system for trucks on motorways. Thus, vehicles can be charged with an efficient toll. Therefore, traffic volumes tend to be shifted away from the morning and evening peaks, e.g., logistics companies can shift inner city deliveries into night times, helping to decrease congestion.

The research objective is to evaluate a pricing system concept based on GNSS and to show the advantages of introducing such systems for urban road pricing systems. We evaluate the expected cost of introducing these systems especially for logistics companies (last-mile deliveries). This cost increase analysis will prepare the way for a cross-sectoral input-output analysis in order to evaluate the total economic excess burden of urban pricing systems, including the increased transport cost and therefore the overall increase in prices and services 
(regarding transport chains with a source or destination in urban areas).

Our paper concentrates on two relevant aspects: the technological aspect and the aspect of system and sector-relevant costs. To implement an adequate system, all significant aspects would have to be taken into account. The failure of present pricing schemes to relieve current peaks is a central problem of pricing schemes. This might be a hurdle for the implementation of further systems. The paper suggests that this issue might be mitigated by using a GNSS system that allows for load-dependent pricing and gives incentives to efficiently use roads, especially for logistics companies. It indicates that these systems might be introduced at reasonable cost if there is flexibility for last-mile logistics. The introduction of this concept evaluation allows for the first time a comparison of different existing road pricing systems with pricing systems based on GNSS including the occurring costs for the logistics and retail sector.

This research paper therefore attempts to provide a first draft calculation for the cost effects of different city toll schemes on logistics, i.e., last-mile transport. The paper is structured as follows: Section 2 presents the different feasible toll schemes in cities; in Section 3, a first rough analysis of cost implications for last-mile transports is conducted; additionally, Section 4 provides decision options for logistics managers in coping with toll schemes in cities; this is evaluated in Section 5 with an adjusted SWOT (strengths-weaknesses-opportunities-threats) analysis in relation to the different urban toll schemes; Section 6 finally presents a conclusion.

\section{Description of City Toll Schemes}

Concurrently, in this section, three different urban road pricing systems are described: the London Congestion Charge and the Stockholm Congestion Charge as examples for cordon pricing and a theoretical GNSS-based area pricing scheme, modeled on the San Diego I-15 Hot Lanes as an example for corridor pricing.

\subsection{London Congestion Charge}

The London Congestion Charge has been introduced in 2003 as an area license with a flat rate character. The standard charge that is applied to private cars and commercial vehicles entering the charging zone during the charging time (Monday to Friday, 7:00 a.m. to 6:30 p.m.) is $£ 10$. Once entering this zone, each driver can use the inner city roads without any further charging. The charging zone is known as "central London", a 22 square kilometers area. Inhabitants of central London receive a $90 \%$ discount on the charge. There are certain types of vehicles exempt from charging: bicycles, motorbikes, buses, taxis, cars used by disabled travelers, alternative fuel vehicles, fire fighters, emergency vehicles, etc.. The enforcement of the charging is realized by about 200 video cameras that are installed at every entry point of the charging zone. An ANPR (automatic number plate recognition technology) is used to identify vehicles and their drivers obliged to pay the charge. ANPR is able to identify $70 \%$ to $80 \%$ of the cars for a single pass. Since the users usually pass several video cameras, the estimated detection rate is up to $90 \%[10,11]$. A western extension of the charging zone (Kensington, Chelsea) that was introduced in February 2007 was stopped in January 2011.

In literature, the effects of the London Congestion Charge have been interpreted differently. On the one hand, the initial aims of the system - reducing traffic volume, increasing average speed in the city, increasing public transport and additional revenues for investments in public transport [10]-have been achieved so that most reactions are positive $[11,12]$. Furthermore, comparisons of costs and revenues by, e.g., Bowen [13] and Transport for London in 2008 document a net benefit of the system. Transport for London identifies net revenues of $£ 137$ million for the financial year (August 2008). This is due to total revenues of $£ 268$ million and total costs of $£ 131$ 
million. The costs can be differentiated in operational, publicity and enforcement costs of the scheme (£91 million) and other costs like staff costs and costs of traffic management. On the other hand, several authors criticize the effects of the system [14]. Particularly, the inefficiency of the system has been at the centre of criticism. The technology that is limited in the recognition of number plate leads to a reduced effectiveness of the toll system. This is dependent on the toll that does not vary by time-of-day. Fig. 1 illustrates that the greatest portion of the realized traffic reduction concerns off-peak periods in the afternoon. Pre-charging and today's traffic volumes do not differ significantly during the main peaks. This leads to a lack of effectiveness of the scheme that is in line with the moderate congestion cost reduction that is measured in London in the last years [7, 15]. These developments are motivated by the flat rate character of the scheme. If the daily charge is once paid, no incentive for a further minimization of using scarce road space is given. An overview on further critique is given by Bowen [13].

\subsection{Stockholm Congestion Charge}

The Stockholm Congestion Charge was introduced in August 2007 after a temporary trial between January and July 2006. The objectives of the charging were a reduction of traffic volumes, an improved access to the inner city, lower emissions and an improved perception of the inner-city environment by the population. The trial consisted of three components: the introduction of urban road pricing, the improvement of public traffic and the promotion of park and ride facilities. Each road user had to pay a certain time-dependent toll if he passed one of the 18 access points to the city during the charging time, in both directions (Monday to Friday, 6:30 a.m. to $6: 29$ p.m.). In contrary to London, the Stockholm pricing system is time-dependent. During the morning peak (7:30 a.m. to 8:29 a.m.) and the afternoon/evening peak (4:00 p.m. to 5:29 p.m.) higher fees are payable. In the off-peak times, between $6: 30$ p.m. and 6:29 a.m., no toll is payable. Emergency vehicles, fire workers, buses, motorbikes, etc. are exempted from payment. The technology of the system is comparable to the technology used in London. Registration of the vehicles is possible via ANPR or alternatively via on board units. The determination of the data is carried out by cameras, laser detectors and transceivers that are coupled to control points or signal bridges. Data are moved in real-time to data centers $[10,16,17]$. The objectives of the system have been largely achieved. Traffic volume has been reduced by $22 \%$ or some 100,000 vehicles per day on average.

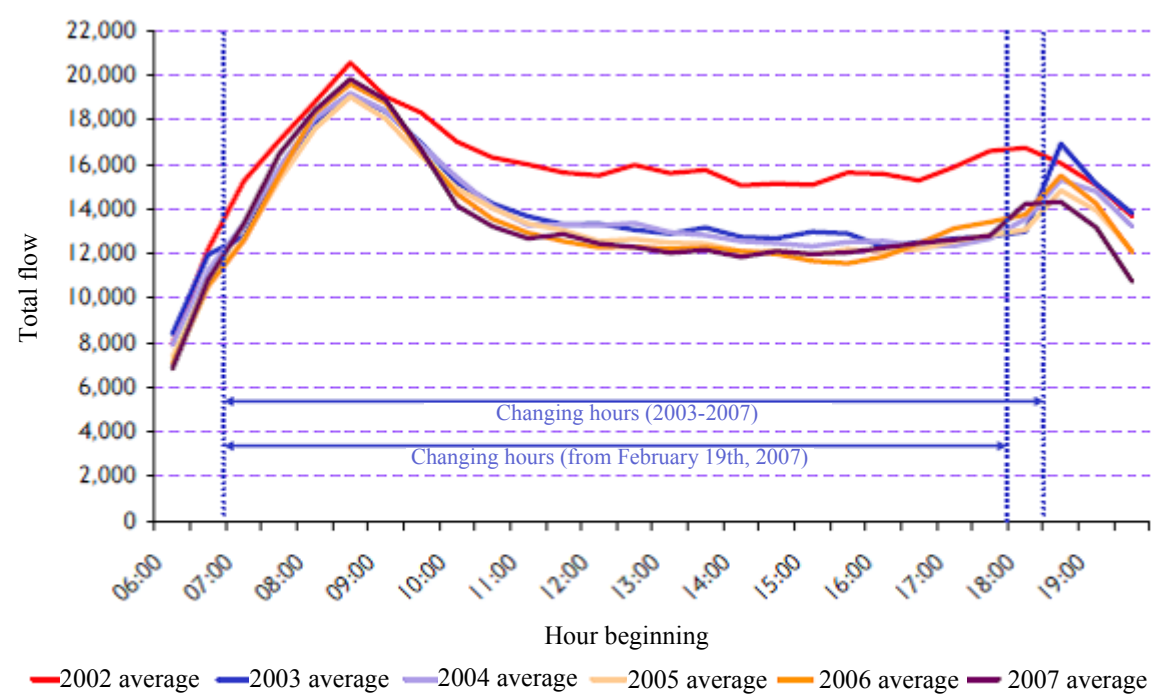

Fig. 1 London traffic changes depending on time of day (2002-2007). 
Fig. 2 outlines the distribution of vehicle passage toward and from the cordon area in vehicles per hour, dependent on time of day, for the periods April 2005, October 2005, April 2006, October 2006 and October 2007 [18].

Similar as in London, cost-benefit analyses document different results of the effects. However, most of the results are positive. Eliasson [19], for example, shows the overall economic benefit of the Stockholm Congestion Charge. In his analysis, he identifies a total socioeconomic surplus of $€ 82$ million per year, excluding the investment costs. An investigation of Transek [20] differentiates between the trial and a permanent introduction of the charging scheme. Looking at the trials only, a benefit-cost ratio of just 0.22 arises. In this case, the measure "road pricing system" is to reject from an overall economic point of view. A long-term introduction and usage of the system result in a benefit-cost ratio of 1.5. An isolated examination of the charging (without the massive investments in public traffic) results in a benefit-cost ratio of 4.9 .

\subsection{I-15 HOT Lanes in San Diego and GNSS Toll Scheme}

HOT lanes or high occupancy/toll lanes are the best approximation to economy first best pricing so far. Drivers of certain vehicles on specific roads pay a toll that is dependent on the demand. This type of pricing is called congestion pricing. There are one or more uncharged lanes and at least one charged lane, the so-called express lane. If there is no congestion on the uncharged lanes, the price of using the express lane is 0 . The more congestion arises, the higher is the price of using the express lane [21]. I-15 HOT lanes in San Diego were the first road project with dynamic pricing and toll levels within a range of US $\$ 0.50$ and US $\$ 8.00$. Congestion is computed by underground sensors that measure the flow rate in dependence of capacity. Every $6 \mathrm{~min}$, the data are actualized to maintain a certain level of service. Potential users of the road or the express lane are informed of the actual toll rates by certain signs so that every traveler can decide whether to use the untolled lanes or the express lane. In case of a breakdown of the untolled lane(s), the price of using the express lane will rise to the maximum of US $\$ 8.00$ [7]. At the I-15, no tolls have to be paid for carpools, vanpools and buses. This is one of the central ideas of the so-called HOT lanes. Incentives are given not to drive on your own but to promote carpooling. The daily traffic on I-15 express lanes ranges from about 200,000 to 300,000 vehicles. In 2003 , time delays were on

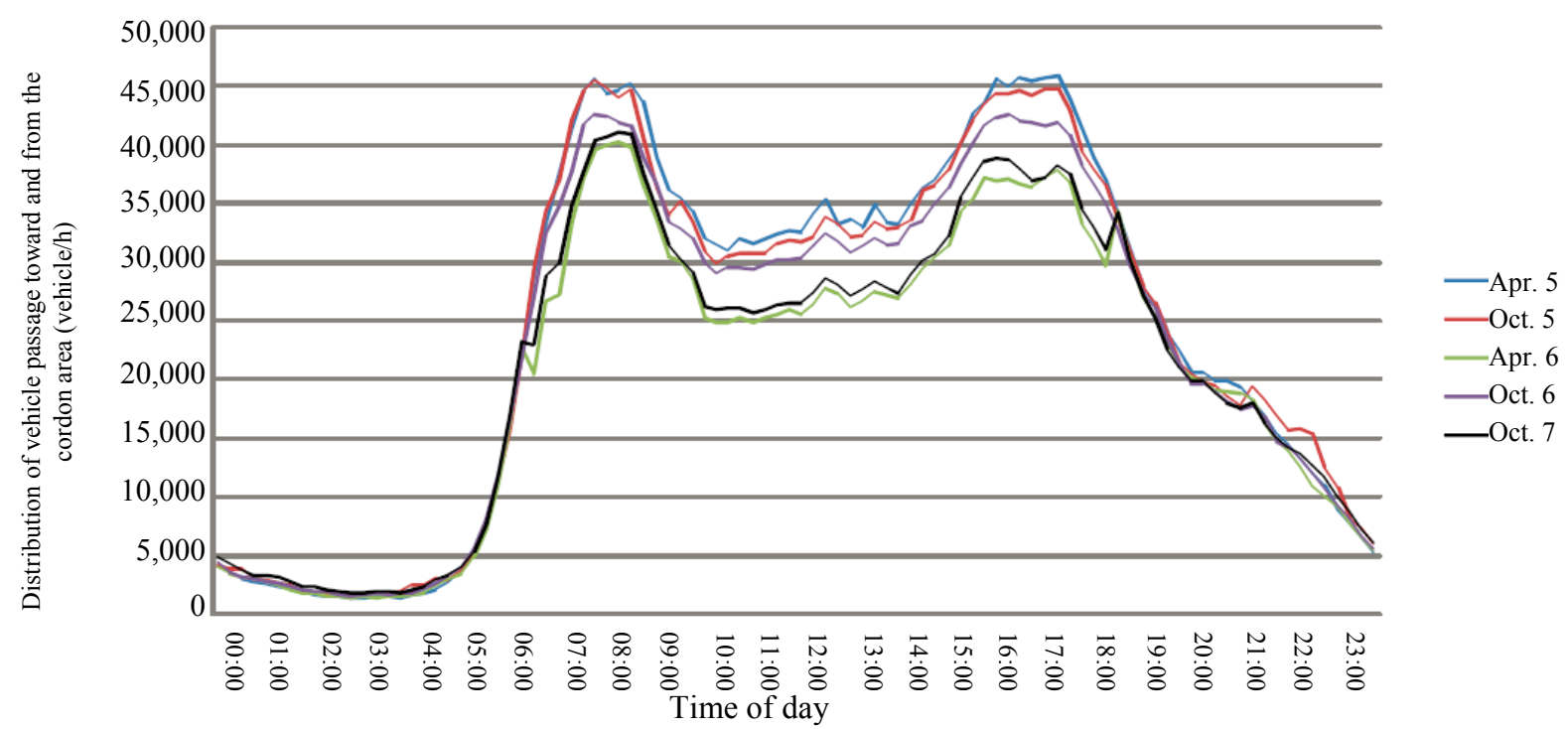

Fig. 2 Stockholm traffic changes depending on time of day 2005-2007. 
average about 30 45 min. According to simulations in 2020 , average delay would have been expanded to 80 90 min without the express lanes.

Combining the described existing cordon and corridor pricing concepts, an "area pricing" scheme can be developed according to traffic and peak patterns. Therein, areas with higher traffic densities could levy higher charges in a GNSS-based city toll system in order to achieve the desired theoretical objectives. This makes sense as especially in these areas where traffic demand exceeds capacities and congestion problems are expected. Table 1 summarizes the comparison of the three pricing systems according to the type of road pricing, the area size, the level of charges and the number of relevant vehicles per day.

\section{Concept Calculation of Cost Burdens on City Transports}

In this section, we analyze the cost burdens on city transports by the introduction of different road pricing systems. Our cost calculation is based on a calculation of actual tour costs (without road pricing) per $100 \mathrm{~kg}$ payload. It differentiates between kilometre-based costs (fuel, etc.) and time-based costs (vehicle, driver). The calculation of kilometre-based costs is based on average kilometres per tour $(80 \mathrm{~km})$, average cost per kilometre (€0.3622 ) and an average maximum payload of $1,310 \mathrm{~kg}$. Time-based costs reflect the assumption of $€ 172$ per day. Table 2 documents that actual tour costs per $100 \mathrm{~kg}$ amount to $€ 15.34$.

The regarded pricing systems (London, Stockholm, GNSS) impose different additional cost burdens on the users. The cost increase per $100 \mathrm{~kg}$ payload in the London case is $+4.67 \%$. This is due to an additional $€ 9.38$ toll divided by the assumed maximum payload of $1,310 \mathrm{~kg}$. The cost increase in the Stockholm case is between $+0.6 \%$ and $+1.2 \%$. This is based on an additional time-dependent toll of $€ 1.2$ to $€ 2.4$, and the assumed maximum payload. The cost increase in the GNSS case is dependent on the traffic situations: we assume that $€ 0.05$ per $\mathrm{km}$ has to be paid at a low level and $€ 0.25$ per $\mathrm{km}$ at a high level of congestion. With these assumptions, the additional cost burdens are between $+1.99 \%$ and $+9.95 \%$. Table 2 shows these calculations in details.

The total cost increase depends on the pricing system.

Table 1 City toll scheme characteristics.

\begin{tabular}{llll}
\hline $\begin{array}{l}\text { Characteristics } \\
\begin{array}{l}\text { Type of road } \\
\text { pricing }\end{array}\end{array}$ & London scheme & Stockholm scheme & GNSS city toll \\
\hline $\begin{array}{l}\text { Area size/distance } \\
\text { 22 km } \mathrm{km}^{2}\end{array}$ & $34 \mathrm{~km}^{2}$ & Area pricing, time-sensitive \\
\hline Charges & 9.38 Euro & $1.20 \sim 2.40$ Euro & Flexible \\
\hline $\begin{array}{l}\text { Number of relevant } \\
\text { vehicles per day }\end{array}$ & $\begin{array}{l}\text { (a) By zoning, i.e., 1 Euro per entered sub-zone or (b) by } \\
\text { distance, i.e., 0.05 0.25 Euro per travelled kilometre } \\
\text { according to traffic situation }\end{array}$ \\
\hline
\end{tabular}

Table 2 Cost impact calculation.

\begin{tabular}{|c|c|c|}
\hline Vehicle costs & Calculation & Vehicle costs/tour/100 kg \\
\hline Kilometer-based costs (fuel, etc.) & $\begin{array}{l}80 \mathrm{~km} \text { per tour on average } \times € 0.3622 \text { per } \mathrm{km} \\
=€ 28.98 \text { per tour }\end{array}$ & $\begin{array}{l}(€ 28.98 \text { per tour divided by } 1,310 \mathrm{~kg} \text { max. payload }) \\
\times 100 \mathrm{~kg}=€ 2.21 \text { per } 100 \mathrm{~kg}\end{array}$ \\
\hline Time-based costs (vehicle, driver) & $\begin{array}{l}172 € \text { per day } \\
\text { (and therefore tour) }\end{array}$ & $\begin{array}{l}(€ 172 \text { per day divided by } 1,310 \mathrm{~kg} \text { max. payload }) \times \\
100 \mathrm{~kg}=€ 13.13 \text { per } 100 \mathrm{~kg}\end{array}$ \\
\hline Tour costs per $100 \mathrm{~kg}$ payload & $100 \%$ & $€ 15.34$ (per $100 \mathrm{~kg})$ \\
\hline Cost increase in London case & $+4.67 \%$ & $\begin{array}{l}\text { (Additional } € 9.38 \text { toll divided by } 1,310 \mathrm{~kg} \max \text {. } \\
\text { payload) } \times 100 \mathrm{~kg}=€ 0.72 \text { per100 } \mathrm{kg}\end{array}$ \\
\hline Cost increase in Stockholm case & $+0.60 \%$ to $+1.20 \%$ & $\begin{array}{l}\text { (Additional } € 1.20 \sim € 2.40 \text { toll divided by } 1,310 \mathrm{~kg} \\
\text { max. payload) } \times 100 \mathrm{~kg}=€ 0.09 \text { to } € 0.18 \text { per } 100 \mathrm{~kg}\end{array}$ \\
\hline Cost increase in GNSS case & $+1.99 \%$ to $+9.95 \%$ & $\begin{array}{l}\text { (Additional } 0.05 \text { to } 0.25 € \text { per } \mathrm{km} \text { at } 80 \mathrm{~km} \text { divided } \\
\text { by } 1,310 \mathrm{~kg} \text { max payload) } \times 100 \mathrm{~kg}=€ 0.31 \text { to } € 1.53 \\
\text { per } 100 \mathrm{~kg}\end{array}$ \\
\hline
\end{tabular}


In the Stockholm case, the additional cost burden might be the lowest $(+0.6 \%$ up to $+1.2 \%)$. In this time-dependent scenario, the users have the alternative and the incentive to shift their transports from the peaks to non-congested times (e.g., night deliveries).

However, total cost increases can be expected to be quite low, though 1 to 4 percent above average ROI/EBIT (return on investment/ earnings before interest and taxes) values in transport and logistics, and therefore probably might cause for reactions in the logistics sector (Section 4).

\section{Decision and Management Options for Logistics Concepts}

Section 3 illustrated that the implementation of certain road pricing systems leads to increased costs of the transport companies. However, as seen above, these cost increases are not prohibitively high. Furthermore, road pricing implies a benefit for the regarded users from decreased travel times.

Independently of the type of pricing system, the transport companies do have an incentive to optimize their behaviour and try to save additional toll costs if a pricing system is implemented. There are several reaction options to make use of all saving potentials. Reaction options are as follows:

(1) night deliveries (outside the prices imposed by the toll schemes);

(2) larger vehicles (and less tours);

(3) electric vehicles (and therefore more tours due to lower payload capacities);

(4) combined transport concepts (transhipment at toll scheme borders, like older city logistics concepts);

(5) use of alternative transport modes (streetcar, underground, bike);

Table 3 SWOT analysis according to city toll scheme.

\begin{tabular}{|c|c|c|c|}
\hline Logistics reaction options & London scheme (cordon) & $\begin{array}{l}\text { Stockholm scheme (cordon, } \\
\text { time-sensitive) }\end{array}$ & $\begin{array}{l}\text { GNSS city toll (area- and } \\
\text { time-sensitive) }\end{array}$ \\
\hline $\begin{array}{l}\text { eries } \\
\text { ices impose } \\
\text { emes) }\end{array}$ & $\begin{array}{l}\text { (+) Avoiding toll costs } \\
\text { (-) No steering impact on road } \\
\text { users }\end{array}$ & $\begin{array}{l}\text { (+) Avoiding toll costs-depending } \\
\text { on time zones defined } \\
(-) \text { No steering impact }\end{array}$ & $\begin{array}{l}\text { (+) Avoiding toll costs-depending } \\
\text { on time zones defined } \\
(-) \text { No steering impact }\end{array}$ \\
\hline $\begin{array}{l}\text { (b) Larger vehicles (and } \\
\text { less tours) }\end{array}$ & $\begin{array}{l}\text { (+) Positive cost and } \\
\text { environmental impact (partly } \\
\text { avoiding toll costs) } \\
\text { (-) Increased handling and } \\
\text { process costs for LSP (logistics } \\
\text { service providers) and } \\
\text { consignee }\end{array}$ & $\begin{array}{l}\text { (+) Positive cost and } \\
\text { environmental impact (partly } \\
\text { avoiding toll costs) } \\
\text { (-) Increased handling and process } \\
\text { costs for LSP and consignee }\end{array}$ & $\begin{array}{l}\text { (+) Positive environmental impact } \\
(+) \text { Areas can be defined for } \\
\text { different truck sizes (positive } \\
\text { steering effect) } \\
\text { (-) Increased handling and process } \\
\text { costs for LSP and consignee }\end{array}$ \\
\hline $\begin{array}{l}\text { (c) Electric vehicles (and } \\
\text { therefore more tours due to } \\
\text { lower payload capacities) }\end{array}$ & $\begin{array}{l}\text { ling toll costs } \\
\text { tronger increase in } \\
\text { ansport costs due to } \\
\text { ehicles and more tours }\end{array}$ & $\begin{array}{l}\text { sts } \\
\text { crease in } \\
\text { ts due to } \\
\text { more tours }\end{array}$ & $\begin{array}{l}\text { (+) Avoiding toll costs } \\
(-) \text { Even stronger increase in overall } \\
\text { transport costs due to electric } \\
\text { vehicles and more tours }\end{array}$ \\
\hline $\begin{array}{l}\text { (d) Combined transport } \\
\text { concepts (transhipment at } \\
\text { toll scheme borders, like } \\
\text { older city logistics } \\
\text { concepts) }\end{array}$ & $\begin{array}{l}\text { (+) Avoiding toll costs partly } \\
(-) \text { Larger increase in overall } \\
\text { transport costs due to } \\
\text { transhipment (additional } \\
\text { handling) costs }\end{array}$ & $\begin{array}{l}\text { (+) Avoiding toll costs partly } \\
(-) \text { Larger increase in overall } \\
\text { transport costs due to } \\
\text { transhipment (additional } \\
\text { handling) costs }\end{array}$ & $\begin{array}{l}(+) \text { Avoiding toll costs partly } \\
\text { (-) Larger increase in overall } \\
\text { transport costs due to transhipment } \\
\text { (additional handling) costs }\end{array}$ \\
\hline $\begin{array}{l}\text { (e) Use of alternative } \\
\text { transport modes (streetcar, } \\
\text { underground, bike) }\end{array}$ & $\begin{array}{l}\text { (+) Avoiding toll costs } \\
\text { (-) Increase in overall transport } \\
\text { costs due to system costs } \\
\text { (investment, training, missing } \\
\text { flexibility) }\end{array}$ & $\begin{array}{l}\text { (+) Avoiding toll costs } \\
\text { (-) Increase in overall transport } \\
\text { costs due to system costs } \\
\text { (investment, training, missing } \\
\text { flexibility) }\end{array}$ & $\begin{array}{l}(+) \text { Avoiding toll costs } \\
\text { (-) Increase in overall transport costs } \\
\text { due to system costs (investment, } \\
\text { training, missing flexibility) }\end{array}$ \\
\hline $\begin{array}{l}\text { (f) Tour direction changes } \\
\text { (avoiding most of the toll } \\
\text { areas if possible but leading } \\
\text { to longer routes) }\end{array}$ & $\begin{array}{l}\text { (+) Avoiding toll costs partly } \\
\text { (-) Increase in transport costs } \\
\text { due to longer tours } \\
\text { (detour) - total effect depending } \\
\text { on toll level }\end{array}$ & $\begin{array}{l}\text { (+) Avoiding toll costs partly } \\
\text { (-) Increase in transport costs due } \\
\text { to longer tours (detour)-total } \\
\text { effect depending on toll level }\end{array}$ & $\begin{array}{l}\text { (+) Avoiding toll costs partly } \\
\text { (-) Increase in transport costs due to } \\
\text { longer tours (detour)- total effect } \\
\text { depending on toll level }\end{array}$ \\
\hline
\end{tabular}

$(+)$ For positive effects, (-) for negative effects. 
(6) tour direction changes (avoiding most of the toll areas if possible but leading to longer routes).

\section{SWOT Analysis of Logistics Management Options}

The analysis so far has shown that, given the implementation of a road pricing scheme, a time-dependent toll might be the best of all the bad alternatives for transport companies. This is due to the fact that, in this case, they have the best possibilities to react. In this case, as shown in Section 3, only moderate cost increases might occur. Furthermore, potential benefits from decreasing time costs as a consequence of the implementation of a pricing scheme have to be taken into account.

Table 3 outlines the specific impacts of different city toll schemes on the six suggested measure options for logistics.

Obviously, most options for logistics possess advantages and disadvantages at the same time. The most interesting option are maybe night deliveries. Therefore, such concepts can be expected more and more in last-mile distribution concepts in the future. Furthermore, it becomes obvious during this analysis that the toll scheme as described has little differing impact on the six action suggestions.

\section{Conclusions}

The described research has outlined the theoretical options (base models) for city toll systems, which can be expected to evolve in urban transport systems all over Europe in the next 10 20 years. According to these schemes, an evaluation of the impacts for last mile transports has been conducted and management or decision options have been suggested and evaluated, depending on the specific nature of the city toll system. This will enable further research regarding impact analysis of such schemes for the logistics and transport sector as well as provide first hints for possible action and concepts for the case of already implemented city toll systems for transport managers. Regarding the six described first set of reaction options for logistics regarding city toll systems, the following observations and future research questions have to be highlighted:

- Night deliveries, feasible due to noise and entrance restrictions, will gain importance and attract concept research in urban logistics;

- Larger vehicles do not seem that attractive and are defined mainly by regulation restrictions anyway. In Germany for example, the motorway toll classes are dominantly defined truck, sized to be changed from 12 $\mathrm{t}$ to $7.5 \mathrm{t}$;

- Electric vehicles will also see a surge in interest and research regarding future urban transport also in the concept of toll systems though the major backlog here is not the toll cost question but the payload question due to heavy battery weights (not feasible for higher/larger payload trucks);

- Innovative transport concepts and modes will gain much importance in a long-term perspective as usually strategic planning and investment have to be involved. But, e.g., for newly planned city districts and areas, this will be a major research and business question;

- Tour optimization does not look that promising from our analysis regarding toll regimes in urban areas - this might change when the level of toll fees would be rising significantly, but for the current levels employed in the example areas in Europe, impact on tour planning might be minimal;

- Finally, it has to be stressed that for all management alternatives, a crucial trade-off between running and fixed (investment) costs have to be observed.

\section{References}

[1] Fosgerau, M., and van Dender, K. 2012. Road Pricing with Complications. New York: Forthcoming Transportation.

[2] Marner, T. 2006. "Die Modellierung Innerstädtischer Staus und die Wirkungsweise Ausgewählter Wirtschaftspolitischer Maßnahmen-Eine Spieltheoretische Analyse (Modeling of Inner-City Congestion and Effects of Selected Economic Measures a Game-Theory Analysis)." Zeitschrift für 
Verkehrswissenschaft 77 (3): 199-225. (in German)

[3] Walters, A. A. 1961. "The Theory and Measurement of Private and Social Cost of Highway Congestion." Econometrica 29 (4): 676-99.

[4] European Commission. 2011. Roadmap to a Single European Transport Area-Towards a Competitive and Resource Efficient Transport System. Brussels: European Commission.

[5] Klumpp, M., Bioly, S., and Sandhaus, G. 2012. "Methods, Inputs and Examples for Future Transport Volume Prognosis in Germany." In Pioneering Supply Chain Design-A Comprehensive Insight into Emerging Trends, Technologies and Applications, edited by Blecker, T., Kersten, W., and Ringle, C. M. Köln: Josef Eul Verlag Gmbh, 147-59.

[6] Klumpp, M., Clausen, U., and tenHompel, M. 2013. "Logistics Research and the Logistics World of 2050." In Efficiency in Logistics, Lecture Notes in Logistics, edited by Clausen, U., ten Hompel, M., and Klumpp, M. Heidelberg: Springer, 1-6.

[7] Murray, P. 2012. "Congestion Pricing for Roads: An Overview of Current Best Practice, and the Economic and Transport Benefits for Government." Public Infrastructure Bulletin 1 (8): Art. 8.

[8] Klumpp, M., Moctar, B., Kandel, C., and Hitzbleck, K. 2011. "GPS Geofencing for Location-Based $\mathrm{CO}_{2}$ Calculation within Port Areas." In Maritime Logistics in the Global Economy-Current Trends and Approaches, edited by Blecker, T., Jahn, C., and Kersten, W. Köln: Books on Demand, 39-55.

[9] Zabic, M. 2011. "GNSS-Based Road Charging Systems." Ph.D. thesis, Technical University of Denmark.

[10] Eisenkopf, A. 2008. "Urban Access Charging-An Efficient Means of Urban Transport Management?." Presented at 13th ACEA (European Automobile
Manufacturers' Association) SAG (Scientific Advisory Group) Meeting, Brussels, Belgium.

[11] Leape, J. 2006. "The London Congestion Charge." Journal of EconomicPerspectives 20 (4): 157-76.

[12] Santos, G., and Shaffer, B. 2004. "Preliminary Results of the London Congestion Charging Scheme." Public Works Management and Policy 9 (2): 164-81.

[13] Bowen, D. 2010. "The London Congestion Charging Scheme: A Cost-Benefit Analysis." B.Sc. thesis, Duquesne University.

[14] Prud'homme, M., and Bocarejo, J. P. 2005. "The London Congestion Charge: A Tentative Economic Appraisal." Transport Policy 12 (3): 279-88.

[15] Transport for London. 2008. Central London Congestion Charging Impacts Monitoring. Sixth annual report, London.

[16] Börjesson, M., Eliasson, M. B., Hugosson, K., and Brundell-Freij, K. 2012. "The Stockholm Congestion Charges - 5 years on Effects, Acceptability and Lessons Learnt." Transport Policy 20 (March): 1-12.

[17] Marner, T. 2007. "City-Maut in Stockholm-Eine Politökonomische Analyse (City Toll in Stockholm-A Political-Economic Analysis). Internationales Verkehrswesen 59 (11): 505-11. (in German)

[18] Baradaran, S., and Firth, D. 2008. "Congestion Tax in Stockholm. An Analysis of Traffic before, during and after the Trial and since the Start of the Permanent Scheme." In Ecocity World Summit 2008 Proceedings, 1-11.

[19] Eliasson, J. 2009. "A Cost-Benefit Analysis of the Stockholm Congestion Charging System." Transportation Research Part A: Policy and Practice 43 (4): 468-80.

[20] Transek. 2006. Equity Effects of the Stockholm Trial. Transek report 2006, Stockholm.

[21] Konishi, H., and Mun, S. 2010. "Carpooling and Congestion Pricing." Regional Science and Urban Economics 40 (4): 173-86. 